\title{
The effect of unstable-surface functional exercises on static balance in adolescents with intellectual disability - a preliminary report
}

\section{Wpływ ćwiczeń funkcjonalnych z wykorzystaniem powierzchni niestabilnych na równowagę statyczna młodzieży z niepełnosprawnością intelektualna - doniesienie wstępne}

\author{
Edyta Mikołajczyk¹, Agnieszka Jankowicz-Szymańska² \\ 'Department of Physiotherapy, University School of Physical Education, Krakow, Poland \\ Head of the Institute: Prof. Marek Pieniążek \\ Institute of Health, State Higher Vocational School, Tarnow, Poland \\ Head of the Institute: Prof. Ryszard Żarów
}

Key words: intellectual disabilities, functional exercises, static balance.

Słowa kluczowe: niepełnosprawność intelektualna, ćwiczenia funkcjonalne, równowaga statyczna.

\begin{abstract}
Introduction: Independent and safe mobility considerably affects social functioning and performing activities of daily living (ADL). People with intellectual disabilities commonly have a reduced sense of balanced posture.

Aim of the research study: Examination static balance in adolescents with moderate intellectual disabilities under the influence of a 12-week programme of functional exercises on unstable surfaces.

Material and methods: Static balance was assessed on an Alfa stabilometric platform. A total of 34 adolescents, aged 14-16 years, were involved in the tests. They were divided into two groups: group one took part in a 12-week exercise programme, and group two constituted a control group.

Results: A statistically significant difference $(p<0.05)$ between the scores of the experimental and control group was revealed after the termination of the exercise programme, and it related to the Centre of Pressure (COP) surface area in the balance assessment test with eyes closed. The suggested battery of exercises considerably $(p<0.05)$ affected the shortening of the path length in the balance assessment test with eyes open. Those differences were not observed in the control group. The experimental group boasted a statistically significant $(p<0.05)$ shortening of the path length and a smaller surface area covered by the COP in exercises with eyes closed.

Conclusions: The suggested training programme improved static balance in intellectually disabled adolescents who took part in regular exercise sessions.
\end{abstract}

\section{Streszczenie}

Wstęp: Niezależna i bezpieczna mobilność ma istotne znaczenie dla udziału w życiu społecznym i codziennych aktywnościach. U osób niepełnosprawnych intelektualnie częstym problemem jest zmniejszone poczucie zrównoważonej postawy ciała.

Cel pracy: Zbadanie jakości równowagi statycznej młodzieży z niepełnosprawnością intelektualna umiarkowanego stopnia po przeprowadzeniu 12-tygodniowego programu ćwiczeń funkcjonalnych z wykorzystaniem powierzchni niestabilnych. Materiał i metody: Jakość równowagi oceniono przy użyciu platformy stabilometrycznej Alfa AC International East (dystrybutor P.H.U. Technomex). W badaniach uczestniczyło 34 dzieci w wieku 14-16 lat, które podzielono na dwie grupy: pierwsza uczestniczyła w 12-tygodniowym programie ćwiczeń funkcjonalnych z wykorzystaniem powierzchni niestabilnych, natomiast druga stanowiła grupę kontrolną.

Wyniki: Statystycznie istotną różnicę $(p<0,05)$ pomiędzy wynikami osób z grupy eksperymentalnej w porównaniu z grupą kontrolną zaobserwowano po zakończeniu programu ćwiczeń dla pola powierzchni w warunkach oczu zamkniętych. Zaproponowany program ćwiczeń znacząco $(p<0,05)$ wpłynął na zmniejszenie się długości ścieżki w badaniu równowagi w warunkach oczu otwartych. Różnic tych nie zanotowano w grupie kontrolnej. Po wyłączeniu kontroli wzroku w badaniu w grupie eksperymentalnej stwierdzono istotne statystycznie $(p<0,05)$ skrócenie się długości ścieżki oraz zmniejszenie się pola powierzchni zakreślonego przez środek nacisku.

Wnioski: Zaproponowany program ćwiczeń wpłynął na poprawę równowagi statycznej młodzieży niepełnosprawnej intelektualnie uczestniczącej regularnie w zajęciach. Wyniki badań zachęcają do ich kontynuacji. 


\section{Introduction}

The primary objective of the human vestibular system is to maintain a solid centre of gravity (COG) under static conditions and in motion. Swaying of the COG in different directions is controlled within its base of support (BOS), located in the area where the feet adhere to the surface. Keeping postural stability is possible thanks to the cooperation of the organ of vision, proprioceptors and the vestibular system [1]. Information flowing from those centres causes involuntary reactions of the musculoskeletal system of the limbs and the trunk, correcting the position of the COG and assuring stability of a standing posture or enabling effective, aesthetic and economic ambulation [2]. In the intellectually disabled, functional limitations - expressed by worse body posture, gait and performance in activities of daily living (ADL) - result considerably from worse postural balance.

\section{Aim of the research study}

The pilot studies aimed to assess changes in static balance in adolescents with moderate intellectual disabilities (ID) under the influence of an original 12 -week programme of unstable-surface functional exercises.

\section{Material and methods}

A total of 34 adolescents with moderate mental disabilities (aetiology other than genetic syndrome) students of the Group of Special Education Schools in Krakow - were involved in the study. The participants' average age bracket was 14-16 (15.06 \pm 0.9$)$ years, their average body weight equalled $65.5 \pm 13.1 \mathrm{~kg}$ and their average body height was $163.3 \pm 8.7 \mathrm{~cm}$. All of them willingly took part in the programme and obtained their legal guardians' informed consent in writing.

The authors of the study obtained written permissions from the school authorities and the Bioethics Committee at the District Medical Association in Krakow to carry out the project. All procedures were conducted according to the highest ethical standards.

Static balance was measured on an ALFA AC International East stabilometric platform (distributed by P.H.U. Technomex Sp. z.o.o). Participants were asked to assume a comfortable, natural standing position with their upper extremities hanging loosely along their trunks and their feet placed hip-width apart in the middle of the platform. The angular values of the foot positioning of each participant were recorded in the examination protocol because another measurement was repeated in the same standing position. Static balance was assessed by means of the Romberg test. The computer analysis allowed us to obtain the following data: mean deviation of the center-of-pressure (COP) on the $\mathrm{X}$ (COP deviation range in the maximum likelihood (ML) direction) and on the Y axis (COP de- viation range in the AP direction) $[\mathrm{cm}]$, the length of the path covered by the COP $[\mathrm{cm}]$ and the COP surface area $\left[\mathrm{cm}^{2}\right]$ covered on the platform.

All participants, prior to the measurements on the platform, were randomly divided into two equal groups. The adolescents from the experimental group underwent a 12-week intervention programme of exercises on unstable surfaces. Those who did not perform any exercises constituted a control group. The exercise sessions lasted $45 \mathrm{~min}$ each and were conducted three times a week by the same therapists.

Examples of a battery of exercises included in the programme:

- two feet standing on an air-cushion - balance test;

- standing on two air-cushions and alternate lifting of the lower extremity bent at the knee joint;

- sitting on a stability ball and balancing the pelvis with alternate hand reaching forward and diagonally to grasp a mug standing on a table;

- supported kneeling on two air-cushions with alternate upper extremity reaching forward to touch a balloon hanging in front of the participant;

- stepping on 10 air-cushions, placed $40 \mathrm{~cm}$ apart, to get a book lying on a table and return it to the therapist;

- sitting on a stability ball, lifting the lower extremity and putting on and taking off footwear;

- sitting on a stability ball and assuming a standing position; participants were asked to reach a shelf with their upper extremity, take off a toy animal and return to a sitting position;

- cross-legged sitting on an air-cushion, backs straight and palms on their knees; participants were asked to bend forward and touch with their palms the palms of the therapist and then return to the initial position;

- lying on the back, the lower extremities bent at the knees, feet placed on cushions; trunk turning to the sides, moving a ball from one side to the other;

- four elastic tapes fixed across the room at a distance of $1 \mathrm{~m}$ and at the alternate height of the participants' knees and shoulders; the test involved getting to the other side of the room across a surface covered with soft mattresses, over the lowest and under the highest tapes;

- moving sideways over a bridge made of air-cushions lying in two rows.

Another static balance test was carried out in both groups after a lapse of 12 weeks of the training programme. The same person made assessments using the same devices, and the tests were conducted in the presence of a teacher.

\section{Statistical analysis}

The arithmetic mean and the standard deviation of separate variables were calculated. The significance of differences in the values of variables between 
the groups before and after the intervention programme of exercises were assessed by means of the $U$ Mann-Whitney test, if the variable distribution differed from normal (the Shapiro-Wilk test, $\alpha=0.05$ ) or the $t$ test for independent groups, if the distribution was normal.

The significance of variable differences found in both tests in the experimental and control group were also analysed employing the Wilcoxon sequence pair test for the variables whose distribution differed from normal; the level of significance was accepted at $\alpha=0.05$.

\section{Results}

The results of the static balance tests were statistically analysed and are presented in Tables 1 and 2 .

Prior to commencing exercises, there were no statistically significant differences noticed between both groups as for the variables under analysis in the static balance test performed with eyes open (Table 1). The average results characterising both groups after the lapse of 12 weeks differed to a greater extent from those in the initial test; however, they were not of statistical significance.

A statistically significant difference $(p<0.05)$ relating to swaying of the COP in the anterior-posterior direction (Y) was recorded before commencing the intervention programme of exercises between both groups when the tests were performed with eyes closed. The control group had statistically better scores; however, those differences were not recorded after 12 weeks of the intervention programme, at which time those who performed exercises on unstable surfaces scored better. A statistically significant difference $(p<0.05)$, related to the COP surface area, between the results of the participants who performed exercises with their eyes closed and those who did not train, was observed after the intervention programme. The average value of that variable was similar in both groups at the beginning of observations, while after the lapse of 12 weeks of the intervention programme it distinctly differed to the benefit of those who had trained.

Statistical analysis showed that the suggested intervention programme considerably $(p<0.05)$ affected the shortening of the path length in the balance test performed with eyes open (Table 2). Those differences were not recorded in the control group. After progressing to eyes closed, the experimental group presented statistically significant $(p<0.05)$ shortening of the path length and a decrease in the surface area covered by the COP, while the control group did not record statistically significant differences relating to the variables under analysis. The group of adolescents who underwent the original unstable-surface intervention programme of exercises revealed a considerable tendency to improve the level of all variables under analysis.

\section{Discussion}

Nowadays, most parents of intellectually disabled children do their best to provide them with a good standard of living and developmental possibilities. Disabled young people can attend various occupational therapy workshops and are taken care of by dif-

Table 1. Intergroup comparison at the beginning and at the end of observations

\begin{tabular}{|c|c|c|c|c|c|c|}
\hline \multirow[t]{2}{*}{ Variable } & & & \multicolumn{2}{|c|}{ Pre } & \multicolumn{2}{|c|}{ Post } \\
\hline & & & Group E & Group C & Group E & Group C \\
\hline \multirow{8}{*}{$\begin{array}{l}\text { Eyes } \\
\text { open }\end{array}$} & \multirow{2}{*}{$\begin{array}{l}\text { COP deviations range } \\
\text { in } M L \text { direction }(X)\end{array}$} & $x \pm \mathrm{SD}$ & $-0.76 \pm 2.10$ & $-0.84 \pm 1.76$ & $-0.29 \pm 1.64$ & $-0.82 \pm 2.74$ \\
\hline & & $p$ & \multicolumn{2}{|c|}{0.95} & \multicolumn{2}{|c|}{0.31} \\
\hline & \multirow{2}{*}{$\begin{array}{l}\text { COP deviations range } \\
\text { in AP direction }(Y)\end{array}$} & $x \pm \mathrm{SD}$ & $0.88 \pm 1.32$ & $0.43 \pm 1.21$ & $0.74 \pm 1.08$ & $1.02 \pm 1.05$ \\
\hline & & $p$ & \multicolumn{2}{|c|}{0.10} & \multicolumn{2}{|c|}{0.36} \\
\hline & \multirow{2}{*}{ Path lenght } & $x \pm \mathrm{SD}$ & $60.73 \pm 40.35$ & $76.14 \pm 47.45$ & $43.45 \pm 30.3$ & $63.91 \pm 44.70$ \\
\hline & & $p$ & \multicolumn{2}{|c|}{0.32} & \multicolumn{2}{|c|}{0.08} \\
\hline & \multirow{2}{*}{ Path area } & $x \pm \mathrm{SD}$ & $24.25 \pm 44.07$ & $17.90 \pm 23.06$ & $8.63 \pm 10.06$ & $12.98 \pm 22.17$ \\
\hline & & $p$ & \multicolumn{2}{|c|}{0.37} & \multicolumn{2}{|c|}{0.38} \\
\hline \multirow{8}{*}{$\begin{array}{l}\text { Eyes } \\
\text { closed }\end{array}$} & \multirow{2}{*}{$\begin{array}{l}\text { COP deviations range } \\
\text { in } M L \text { direction }(X)\end{array}$} & $x \pm \mathrm{SD}$ & $-0.38 \pm 1.77$ & $-0.95 \pm 2.30$ & $-0.13 \pm 1.77$ & $-0.78 \pm 2.96$ \\
\hline & & $p$ & \multicolumn{2}{|c|}{0.85} & \multicolumn{2}{|c|}{0.34} \\
\hline & \multirow{2}{*}{$\begin{array}{l}\text { COP deviations range } \\
\text { in AP direction }(Y)\end{array}$} & $x \pm \mathrm{SD}$ & $1.18 \pm 1.38$ & $0.20 \pm 1.18$ & $0.76 \pm 1.16$ & $0.88 \pm 1.43$ \\
\hline & & $p$ & \multicolumn{2}{|c|}{$0.04^{*}$} & \multicolumn{2}{|c|}{0.79} \\
\hline & \multirow{2}{*}{ Path lenght } & $x \pm \mathrm{SD}$ & $64.59 \pm 41.7$ & $72.17 \pm 46.1$ & $41.3 \pm 29.69$ & $62.54 \pm 43.11$ \\
\hline & & $p$ & \multicolumn{2}{|c|}{0.51} & \multicolumn{2}{|c|}{0.09} \\
\hline & \multirow{2}{*}{ Path area } & $x \pm \mathrm{SD}$ & $16.75 \pm 17.80$ & $22.95 \pm 39.35$ & $5.67 \pm 7.37$ & $21.05 \pm 39.82$ \\
\hline & & $p$ & \multicolumn{2}{|c|}{0.74} & \multicolumn{2}{|c|}{$0.02^{*}$} \\
\hline
\end{tabular}

*Statistically significant differences 
Table 2. Intra-group comparison at the beginning and at the end of observations

\begin{tabular}{|c|c|c|c|c|c|c|}
\hline \multicolumn{3}{|c|}{ Variable } & \multicolumn{2}{|c|}{ Group E } & \multicolumn{2}{|c|}{ Group C } \\
\hline & & & Pre & Post & Pre & Post \\
\hline \multirow{8}{*}{$\begin{array}{l}\text { Eyes } \\
\text { open }\end{array}$} & \multirow{2}{*}{$\begin{array}{l}\text { COP deviation range in the } \\
\text { ML direction }(X)\end{array}$} & $x \pm \mathrm{SD}$ & $-0.76 \pm 2.10$ & $-0.29 \pm 1.64$ & $-0.84 \pm 1.76$ & $-0.82 \pm 2.74$ \\
\hline & & $p$ & \multicolumn{2}{|c|}{0.12} & \multicolumn{2}{|c|}{0.85} \\
\hline & \multirow{2}{*}{$\begin{array}{c}\text { COP deviation range in the AP } \\
\text { direction }(\mathrm{Y})\end{array}$} & $x \pm S D$ & $0.88 \pm 1.32$ & $0.74 \pm 1.08$ & $0.43 \pm 1.21$ & $1.02 \pm 1.05$ \\
\hline & & $p$ & \multicolumn{2}{|c|}{0.87} & \multicolumn{2}{|c|}{0.10} \\
\hline & \multirow{2}{*}{ Path lenght } & $x \pm S D$ & $60.73 \pm 40.35$ & $43.45 \pm 30.3$ & $76.14 \pm 47.45$ & $63.91 \pm 44.70$ \\
\hline & & $p$ & \multicolumn{2}{|c|}{$0.01^{\star}$} & \multicolumn{2}{|c|}{0.32} \\
\hline & \multirow{2}{*}{ Path area } & $x \pm S D$ & $24.25 \pm 44.07$ & $8.63 \pm 10.06$ & $17.90 \pm 23.06$ & $12.98 \pm 22.17$ \\
\hline & & $p$ & \multicolumn{2}{|c|}{0.07} & \multicolumn{2}{|c|}{0.13} \\
\hline \multirow{8}{*}{$\begin{array}{l}\text { Eyes } \\
\text { closed }\end{array}$} & \multirow{2}{*}{$\begin{array}{l}\text { COP deviation range in the } \\
\text { ML direction }(X)\end{array}$} & $x \pm S D$ & $-0.38 \pm 1.77$ & $-0.13 \pm 1.77$ & $-0.95 \pm 2.30$ & $-0.78 \pm 2.96$ \\
\hline & & $p$ & \multicolumn{2}{|c|}{0.68} & \multicolumn{2}{|c|}{0.92} \\
\hline & \multirow{2}{*}{$\begin{array}{l}\text { COP deviation range in the AP } \\
\text { direction }(\mathrm{Y})\end{array}$} & $x \pm S D$ & $1.18 \pm 1.38$ & $0.76 \pm 1.16$ & $0.20 \pm 1.18$ & $0.88 \pm 1.43$ \\
\hline & & $p$ & \multicolumn{2}{|c|}{0.37} & \multicolumn{2}{|c|}{0.05} \\
\hline & \multirow{2}{*}{ Path lenght } & $x \pm \mathrm{SD}$ & $64.59 \pm 41.7$ & $41.3 \pm 29.69$ & $72.17 \pm 46.1$ & $62.54 \pm 43.11$ \\
\hline & & $p$ & \multicolumn{2}{|c|}{$0.03^{*}$} & \multicolumn{2}{|c|}{0.34} \\
\hline & \multirow{2}{*}{ Path area } & $x \pm S D$ & $16.75 \pm 17.80$ & $5.67 \pm 7.37$ & $22.95 \pm 39.35$ & $21.05 \pm 39.82$ \\
\hline & & $p$ & \multicolumn{2}{|c|}{$0.03^{*}$} & \multicolumn{2}{|c|}{0.78} \\
\hline
\end{tabular}

*Statistically significant differences

ferent institutions and organisations which support their struggle against disabilities. Special education schools play an extremely important role in preparing disabled young people for adult life, because they spend most of their time in them.

Disorders to the locomotor system and limited functional fitness, which accompany intellectual disability, make integration of intellectually disabled youngsters with their peer circles more difficult. Such limitations can also cause their emotional withdrawal, which may result in further worsening of their mental and physical development. Intellectually disabled adolescents score worse in locomotor skills tests as compared to their mentally and intellectually healthy peers [3]. Commonly observed sedentary lifestyle and aversion to physical effort [4] result in weight gain $[5,6]$ and numerous disorders of the locomotor system [7]. A worse postural balance, characteristic of intellectually disabled individuals in comparison with their fully fit peer population [8], limits their physical fitness and exposes them to falls and musculoskeletal injuries [9]. That is why it would be advisable to introduce adequate exercise programmes in special education schools, which would help intellectually disabled adolescents improve their fitness. Rehabilitation methods are still developing and a number of them place strong emphasis on functional training and increasing performance in ADL. The authors of this paper suggested functional exercises imitating daily routines, which could improve their performance in changeable conditions of the outer environment. Whilst carrying out such tasks, participants each time focused on carrying out the task rather than keep- ing balance. Concentration on improving functions and accomplishing individual tasks on unstable surfaces stimulated the participants' balance reactions. According to Horst [10], "function can be defined as a complex activity of the whole body, which aims to accomplish a given task in specific environmental conditions". The intellectually disabled have disturbances to their deep-seated feeling and postural control in comparison with individuals with intellectual norm. Implementation of unstable surfaces in our exercises, i.e. stability balls and air-cushions, aimed to activate proprioceptive input. The shortening of the path length in the experimental group in exercises performed with eyes open in comparison with the control group showed a static balance improvement. Those results corresponded with the scores of the adolescents with Down syndrome [11] in our previous study, in which implementation of unstable surfaces improved their static balance.

A statistically significant shortening of the path length and a decrease in the COP surface area in exercises performed with eyes closed might also show some postural control improvement. Slightly worse scores recorded in exercises with eyes closed, as compared to the ones performed with eyes open, might imply greater concentration of participants on performing tasks when the organ of sight was disabled [12] or a greater fear of falling down [13]. There are a number of reports documenting improvement in static balance among the intellectually disabled following implementation of different intervention programmes. Participation of intellectually disabled youngsters in a 10-week hippotherapy programme, 
consisting of 30-minute sessions twice a week, considerably improved static balance and muscular strength in their lower extremities [14]. Children with ID also scored better in the speed, agility and static balance tests after a special programme of swimming [15]. Other studies showed that compilation of balance exercises and those increasing muscular strength more favourably affected reduction of body weight and improved scores in motor tests in comparison with programmes based solely on general fitness exercises [16].

Bearing in mind that striving to improve the quality of life and self-dependence are the overriding objectives in the process of facilitating persons with ID, one should motivate them to take part in adequate intervention programmes. The battery of successfully completed functional exercises, consisting in accomplishing a given task, additionally stimulated participants to do exercises anew.

\section{Conclusions}

The battery of our original, unstable-surface exercises improved static balance in adolescents with ID who regularly took part in exercise sessions. The results of our tests encourage us to continue research and implement functional exercises on unstable surfaces in a programme of facilitating young people with ID.

\section{References}

1. Olejarz P, Olchowik G. Rola dynamicznej posturografii komputerowej w diagnostyce zaburzeń równowagi. Otorynolaryngologia 2011; 3: 103-110.

2. Held-Ziółkowska M. Równowaga statyczna i dynamiczna ciała. Mag ORL 2006; 18: 39-46.

3. Wieczorek M. Sprawność fizyczna młodzieży niepełnosprawnej intelektualnie jako czynnik warunkujący ich zdrowie. Probl Hig Epidemiol 2008; 2: 235-240.

4. Bryl W, Matuszak K, Hoffmann K. Aktywność fizyczna dzieci i młodzieży niepełnosprawnej intelektualnie - problem zdrowia publicznego. Hygeia Public Health 2013; 1: 1-5.

5. Matuszak K, Bryl W, Pupek-Musialik D. Otyłość u dzieci i młodzieży z upośledzeniem umysłowym. Forum Zaburzeń Metabolicznych 2010; 1: 55-62.

6. Mikołajczyk E, Jankowicz-Szymańska A, Kowalik D, et al. Priorytety w usprawnianiu ruchowym młodzieży z niepełnosprawnością intelektualną. Niepełnosprawność i Rehabilitacja 2012; 4: 34-44.

7. Doody CM, Doody O. Health promotion for people with intellectual disability and obesity. Br J Nurs 2012; 21: 460-465.

8. Blomqvist S, Wester A, Sundelin G, et al. Test-retestreliability, smallest real difference and concurrent validity of six different balance tests on young people with mild to moderate intellectual disability. Physiotherapy 2011; 4: 313-319.

9. Enkelaar L, Smulders E, van Schrojenstein Lantman-de Valk $\mathrm{H}$, et al. A review of balance and gait capacities in relation to falls in persons with intellectual disabilities. Res Dev Disabil 2012; 33: 291-306.
10. Horst R. Trening strategii motorycznych i PNF. Wydawnictwo Top School, Kraków 2010.

11. Jankowicz-Szymańska A, Mikołajczyk E, Wojtanowski W. The effect of physical training on static balance in young people with intellectual disability. Res Dev Disabil 2012; 33: 675-681.

12. Wilczyński J. Analizatory wzroku a reakcje równoważne na przykładzie długości ścieżki posturogramu u uczniów w wieku 12-15 lat. Studia Medyczne 2007; 8: 15-19.

13. Carmeli E, Bar-Yossef T, Ariav C, et al. Sensorimotor impairments and strategies in adults with intellectual disabilities. Motor Control 2008; 12: 348-361.

14. Giagazoglou P, Arabatzi F, Dipla K, et al. Effect of a hippotherapy intervention program on static balance and strength in adolescents with intellectual disabilities. Res Dev Disabil 2012; 33: 2265-2270.

15. Yilmaz I, Ergu N, Konukman F, et al. The effects of water exercises and swimming on physical fitness of children with mental retardation. Journal of Human Kinetics 2009; 21: 105-111.

16. Carmeli E, Zinger-Vaknin T, Morad M, et al. Can physical training have an effect on well-being in adults with mild intellectual disability? Mech Ageing Dev 2005; 126: 299-304.

\section{Address for correspondence:}

Edyta Mikołajczyk PhD

Department of Physiotherapy

University School of Physical Education

al. Jana Pawła II 78, 31-571 Krakow, Poland

Phone: +48 503166667

Fax: +48 126831462

E-mail: edytamiko@gmail.com 